\title{
The Effect of 3-Methyl 1-Pentyn 3-Ol on the Corrosion of Al-Si-Cu Alloys in Acid Solutions by Using SEM, EDX and AAS ${ }^{1}$
}

\author{
A. Buyuksagis ${ }^{\mathrm{a}}$, A. A. Aksut ${ }^{\mathrm{b}}$, and D. Ozal ${ }^{\mathrm{a}}$ \\ ${ }^{a}$ Afyon Kocatepe University Science and Art Faculty, Afyonkarahisar/TURKEY \\ ${ }^{b}$ Ankara University Science Faculty Chemistry Department Ankara/Turkey \\ *e-mail:absagis@aku.edu.tr,ayselbuyuksagis@hotmail.com
}

Received October 2, 2007

\begin{abstract}
In this study, the effect of alloying elements on the corrosion of Al-Si-Cu alloys in $\mathrm{H}_{2} \mathrm{SO}_{4}$ and $\mathrm{HCl}$ media content 3-methyl-1 pentyn-3-ol (3mlp3ol) is investigated by using SEM, EDX, AAS. The effect of active elements and 3-methyl-1-pentyn-3-ol (inhibitor) on the corrosion of alloys is determined using SEM, EDX and AAS results. Experimental results which indicated active alloying elements are $\mathrm{Cu}, \mathrm{Zn}, \mathrm{Mg}$ for $\mathrm{Al}-\mathrm{Si}-\mathrm{Cu}$ alloys in the studied solutions.
\end{abstract}

PACS numbers: $82.45 . \mathrm{Kn}$

DOI: $10.1134 / \mathrm{S} 2070205109030113$

\section{INTRODUCTION}

There are many studies where acidic solutions were used for the process of producing anodic oxide on aluminium surface. These studies generally focus on the topics such as the structure of film, the composition of it, the transferring of ions from oxide, as a result of this the growing mechanism of film, the breakdown of film in the solution-producing oxide etc. Many of these researches were performed by using electron microscope. In recent years, the processes of determination of the structure of film and the oxidation of ion types and its amount have been performed by spectroscopic methods [1-5]. Near eutectic Al-Si alloys are used extensively as piston materials in modern, small automotive engines [5-7]. This class of alloy exhibits complex multiphase microstructures, comprising primary (blocky) and eutectic (acicular) $\mathrm{Si}, \mathrm{Al}$ dendrites and numerous intermetallic particles. Automotive pistons operate under complex mechanical stresses and over a wide temperature range. Through the addition of alloying elements, it is hoped to optimize high temperature fatigue performance without compromising room temperature behaviour. The room temperature fatigue behaviour for these classes of alloy has been studied extensively and has identified porosity as a critical feature [7-10].

However improved casting techniques have reduced porosity considerably. Therefore the influence of Si and intermetallic particles on fatigue behaviour have become more critical [11-16]. Paez et al. (1996) exam-

\footnotetext{
${ }^{1}$ The article is published in the original.
}

ined the formation of type barrier anodic films on $\mathrm{Al}-\mathrm{Cu}$ alloy in their study. At first the formation of type barrier film inside is homogenous and highly productive on the alloy surface of $\mathrm{Al}$ ( polished by electrolytical method) $-3.5 \% \mathrm{Cu}$. Outer parts looking different occur during the anodizing process and the possible structure occurs in anodic film. Zhou et al (1999) investigated anodic oxidation of dual alloys of $\mathrm{Al}-3 \% \mathrm{Mg}$ and $\mathrm{Al}-5 \% \mathrm{Mg}$ in the electrolyte of ammonium pentaborat and type barrier anodic film during the of high current activity. It has been seen that the occurrence of ionic movement of anodic oxide results from both anion and cation migration of amorphous film. Mazhar et al. (2001) state that the corrosion behaviour of $\mathrm{Al}$ obtained in spectrums in EIS study is controlled by multi-stepped dissolving. The breakdown of film layer and oxide result from ions of $\mathrm{Cl}^{-}$. The attack of $\mathrm{Cl}^{-}$ions is due to the occurrence of complex-including $\mathrm{Cl}^{-}$in intersurface of film/solution. This makes passive layer thin and leads to pitting corrosion.

$$
\mathrm{Al}+n \mathrm{Cl}^{-} \longrightarrow \mathrm{AlCl}_{n}^{(n-3)-}+3 \text { é. }
$$

As the acidity of solution increases, the corrosion current $i_{\text {cor }}$ increases, but the polarization resistance decreases. Kowal et al. (1996) researched morphologic variations on the surface of 2024-T3 Al alloy plunged into hydrochloric acidic solution. It was observed that the corrosion of alloy in the mediums including chlorine was in acidic type and $\mathrm{Al}$ alloy was sensitive to corrosion inter grains in hydrochloric acidic medium and have been broken the passiveness of aluminium, there was some dissollutions through the borders of grain. 
Table 1. The composition of the alloys used

\begin{tabular}{c|c|c|r|c|c|c|c|c|c|c|c}
\hline Alloy & $\mathrm{Cu}$ & $\mathrm{Mg}$ & $\mathrm{Si}$ & $\mathrm{Fe}$ & $\mathrm{Mn}$ & $\mathrm{Ni}$ & $\mathrm{Zn}$ & $\mathrm{Pb}$ & $\mathrm{Sn}$ & $\mathrm{Ti}$ & $\mathrm{Cr}$ \\
\hline ETIAL-110 & 3.10 & 0.29 & 5.20 & 0.47 & 0.35 & 0.03 & 0.19 & 0.04 & 0.001 & 0.03 & 0.008 \\
ETIAL-140 & 0.85 & 0.20 & 12.00 & 0.64 & 0.38 & 0.09 & 0.48 & 0.06 & 0.001 & 0.03 & 0.01 \\
ETIAL-150 & 2.35 & 0.23 & 12.30 & 0.82 & 0.26 & 0.08 & 0.58 & 0.04 & 0.02 & 0.03 & 0.01 \\
ETIAL-160 & 3.40 & 0.22 & 8.60 & 0.88 & 0.21 & 0.09 & 0.75 & 0.09 & 0.02 & 0.03 & 0.01 \\
ETIAL-171 & 0.24 & 0.48 & 10.00 & 0.44 & 0.38 & 0.008 & 0.23 & 0.01 & 0.005 & 0.02 & 0.01 \\
ETIAL-195 & 0.94 & 1.02 & 18.23 & 0.23 & 0.011 & 0.97 & 0.004 & - & - & 0.01 & 0.002 \\
\hline
\end{tabular}

Patermarakis and Moussoutzanis (2002) investigated the conditions of pitting occurrence on pure $\mathrm{Al}$ in $\mathrm{H}_{2} \mathrm{SO}_{4}$ solution. As $\mathrm{Al}$ dissolves, the thickness of film decreases on the surfaces where pitting occur. While the process in barrier layer is electrochemical on the surface of porous wall, it is physical and chemical inside. Oxide is formed on the intersurface of metal/oxide according to Faraday's law. Shau et al. (2003) investigated the micro pitting corrosion of 2024T3 alloy by using the scanned micro reference electrode (SMRE) united with SEM and XRD techniques. Just after 2024-T3 alloy plunged into $\mathrm{NaCl}$ solution, the micro pitting started to occur. A few corrosion active seeds developed in a course of time, but the others got lost. Andreatta et al (2004) investigated AA7075 alloy corrosion as morphological of surface characterized using complementary techniques like SEM-EDS, TEM, scanning confocal laser microscopy, scanning Kelvin probe force microscopy and micro-capillary cell. The localized corrosion of AA7075 initiates at the $\mathrm{Cu}$ - and Fe-rich intermetallics due to the presence of a rather high Volta potential difference between the intermetallics and the matrix. It is concluded that the corrosion behaviour of AA7075 is dependent on microstructure changes caused by heat treatment, morphological characterization of various surface insulating films on aluminium. Shimizu (2004) et al. investigated by examination of porous anodic films, barrier anodic films and corrosion product layers by using SEM/STEM. The characterization shows clearly the value of the approaches, particularly the ability to image directly fine details of appropriately prepared aluminium surfaces that have usually required examination by transmission electron microscopy (TEM). Such ready characterization assists mechanistic understanding of the contributions of the macroscopic surface and flaws or second phase to the filming and corrosion processes. Intermetallic phases in sand cast eutectic Al-Si alloys were characterized using a combination of SEM, EDS and EBSD pattern analysis in study Kral's 2004. Chinese script $\alpha$-phase particles were consistent with cubic $\mathrm{Al}_{19}(\mathrm{Fe}, \mathrm{Mn})_{5} \mathrm{Si}_{2}$. Plate-shaped $\beta$-phase particles were consistent with tetragonal $\mathrm{Al}_{3}(\mathrm{Fe}, \mathrm{Mn}) \mathrm{Si}_{2}$. Liao et al. (2002) investigated the amount of dendrites $\alpha$-Al phase with varying $\mathrm{Sr}$ content in near-eutectic $\mathrm{Al}-11.6 \% \mathrm{Si}$ alloy. It was measured by quantitative metallography analysis software and the correlation of mechanical properties of fully modified alloy with the amount of dendrite $\alpha-\mathrm{Al}$ is discussed. Addition of $\mathrm{Sr}$ in $\mathrm{Al}-\mathrm{Si}$ alloys results in a considerable increase of the amount of $\alpha$-Al. Mechanical properties of the fully modified alloy are linearly related to the volume fraction of dendrite $\alpha-\mathrm{Al}$, which plays a key role in improving the mechanical properties of near-eutectic Al-Si alloys. Joyce et al. (2003) considers two candidate automotive piston alloys and highlights the influence of microstructural features on fatigue behaviour. In their study fatigue initiation and subsequent short crack growth were assessed at 20,200 and $350^{\circ} \mathrm{C}$. It is shown that both temperature and test frequency have a strong influence on the fatigue performance of the materials tested. The microstructure was quantitatively characterized in terms of the primary Si distribution. Together with post failure analysis, this allowed identification of critical microstructural features affecting both fatigue crack initiation and early growth. Large primary Si particles were found to act as preferential initiation sites by cracking or decohesion (dependent on test temperature) and are also sought out preferentially during short crack growth.

The aluminium alloys were used in our previous study related to the industrial alloys. The corrosion of these alloys determined by the Tafel's extrapolation and linear polarization methods and the effect of different alcohols on the corrosion of these alloys calculated in these studies [21, 22]. It is concluded that alcohol leads to a decrease in the corrosion of pure copper and aluminium while pure $\mathrm{Zn}, \mathrm{Mg}$, and Fe accelerate the corrosion of alloys in acidic media. This study is planned to confirm our thinks.

\section{EXPERIMENTAL}

In this study, aluminium alloys as working electrode, saturated calomel electrode (SCE) as reference electrode, and platinum wire are used as counter electrode. All the potentials on current-potential curves obtained from experiment are measured against SCE and the results are given according to this electrode. The composition of aluminium alloys used as working electrode is given in Table 1. 

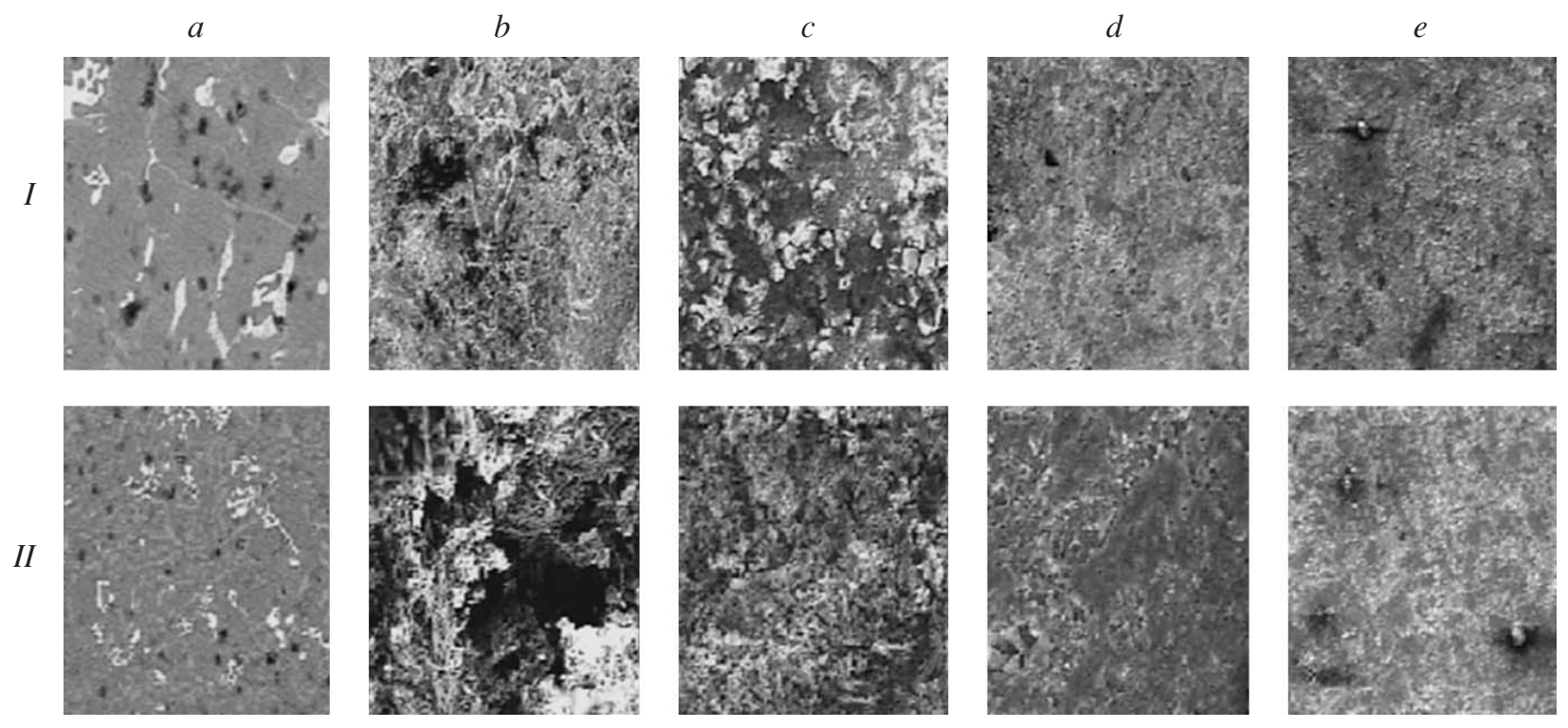

Fig. 1. SEM microphotographies of Al alloys $I-\mathrm{E} 110, I I-\mathrm{E} 140,(a)$ bare surface, (b) $1 \mathrm{~N} \mathrm{HCl},(c) 1 \mathrm{~N} \mathrm{HCl}+20 \mathrm{mM} 3-\mathrm{metil}-$ 1-pentin-3-ol(3m1p3ol), (d) $1 \mathrm{~N} \mathrm{H}_{2} \mathrm{SO}_{4}$ and (e) $1 \mathrm{~N} \mathrm{H}_{2} \mathrm{SO}_{4}+20 \mathrm{mM}$ 3-metil-1-pentin-3-ol.

All the solutions used as electrolyte were prepared with the substances of Merck proanalysis purity and bidistilled water. The SEM microphotographs and the EDX analyses were performed by LEO 1430 VP SEM microscope and the analyses of elements passing through the solution $(\mathrm{Cu}, \mathrm{Fe}, \mathrm{Zn}, \mathrm{Mg}, \mathrm{Al})$ were performed by using VISTA AX atomic absorption equipment.

\section{RESULTS AND DISCUSSIONS}

Two types of films, i.e. barrier and porous films occur according to the type of electrolyte used on the surface of aluminium [23-27]. Ionic conductivity in barrier film comes from cations, oxygen ions, hydrogen ions and other ions (additives in the solutions, and alloy). As a results of chemical reaction between metaloxide and oxide-electrolyte surface developed barrier film metal dissolves and film becomes thick [26, 28]. The porous films at a definite potential occur on aluminium oxide film in $\mathrm{H}_{2} \mathrm{SO}_{4}, \mathrm{CrO}_{4}^{-}, \mathrm{HCO}_{3}, \mathrm{H}_{3} \mathrm{PO}_{4}$ making the effect of solvent in a great amount. The first model for porous film indicated in Polat's study (1997) was stated by Keller et al. (1953) and Hunter and Fowle $(1953,1954)$. When the current is applied first, the barrier film starts to form on surface according to this model. If the formed oxide breaks down in electrolyte, the thickness of the barrier layer starts to decrease. The film thickness as a result of dissolution proceeds simultaneously with the formation of oxide. The pores become open where high current passes through and this current causes the increase of local temperatures which leads to an increase in the corrosion rate. This rise results in increasing of dissolution and as a result of this, the film which is cathode zone becomes thick [23,
29, 30]. Tedeshi (1975) proposed that acetylenic alcohol used for prevention of metal corrosion is more effective in acidic media compared to that of neutral and alkali solutions [31,32]. The acetylenic metal complexes resulted from adsorption can form protective film in active zones where the corrosion proceeds [33]. If the film covers all the surface decisively, high level inhibition occurs. Corrosion potentials of move to negative by adding acetylenic alcohol inhibitors into $\mathrm{H}_{2} \mathrm{SO}_{4}$ medium. This case indicates the effect of inhibitors on the cathode reactions. For this reason, acetylenic alcohol acts as cathodic inhibitor in acidic media $[32,34]$. Some anions like sulphate increase the thickness of oxide layer on metal surface significantly $[8,26$, 28]. The corrosion rates obtained for $\mathrm{Al}-\mathrm{Cu}-\mathrm{Si}$ alloys in $1 \mathrm{~N} \mathrm{H}_{2} \mathrm{SO}_{4}$ medium are given in Table 5. It is seen that the protective film on aluminium surface keeps its occurrence and this situation is confirmed with the experimental results. Having in a low level of dissolution of sulphate salt which would cause on metal surface leads to an increase in the inhibitor efficiency of the oxide film [35].

Microphotographs on the surface of alloys are imaged in SEM. In addition the effect of structure surface of alloys and compositions are determined by EDS. The microphotograph of SEM x500 Al alloys used in research (E110, E140, E150, E160, E171 and E195) surface of bare, $1 \mathrm{~N} \mathrm{HCl}, 1 \mathrm{~N} \mathrm{HCl}+20 \mathrm{mM} 3-$ methyl-1-pentin-3-ol, $1 \mathrm{~N} \mathrm{H}_{2} \mathrm{SO}_{4}$ and $1 \mathrm{~N} \mathrm{H}_{2} \mathrm{SO}_{4}+20 \mathrm{mM}$ 3-methyl-1-pentin-3-ol (3m1p3ol) media after $24 \mathrm{~h}$ plunged in solutions were given in according to the Figs. 1, 3 and 5, it is seen that the alloys in $\mathrm{HCl}$ are corroded more comparing to the $\mathrm{H}_{2} \mathrm{SO}_{4}$ medium. The surface microphotographs also indicate that the surface of electrode has more homogeneous structure and is less 
Table 2. EDX analyses results of E110, E140, E150 alloys stored during 24 hours in acid and containing inhibitor acid solutions

\begin{tabular}{|c|c|c|c|c|c|}
\hline Sample & & Element & $\%$ atom & Type of oxide & wt $\%$ oxide \\
\hline \multirow[t]{10}{*}{ E110 } & \multirow[t]{3}{*}{ bare } & Aluminium & 61.77 & $\mathrm{Al}_{2} \mathrm{O}_{3}$ & 78.88 \\
\hline & & Silicon & 13.57 & $\mathrm{SiO}_{2}$ & 20.42 \\
\hline & & Copper & 0.35 & $\mathrm{CuO}$ & 0.70 \\
\hline & \multirow[t]{4}{*}{$\mathrm{HCl}+\mathrm{inh}$} & Aluminium & 12.12 & $\mathrm{Al}_{2} \mathrm{O}_{3}$ & 40.44 \\
\hline & & Silicon & 10.87 & $\mathrm{SiO}_{2}$ & 42.77 \\
\hline & & Copper & 1.75 & $\mathrm{CuO}$ & 9.12 \\
\hline & & Chlorur & 3.31 & $\mathrm{Cl}^{-}$ & 7.68 \\
\hline & \multirow[t]{3}{*}{$\mathrm{H}_{2} \mathrm{SO}_{4}+\mathrm{inh}$} & Aluminium & 66.98 & $\mathrm{Al}_{2} \mathrm{O}_{3}$ & 84.25 \\
\hline & & Silicon & 9.94 & $\mathrm{SiO}_{2}$ & 14.74 \\
\hline & & Copper & 0.52 & $\mathrm{CuO}$ & 1.01 \\
\hline \multirow[t]{10}{*}{ E140 } & \multirow[t]{3}{*}{ bare } & Aluminium & 54.76 & $\mathrm{Al}_{2} \mathrm{O}_{3}$ & 68.46 \\
\hline & & Silicon & 21.40 & $\mathrm{SiO}_{2}$ & 31.54 \\
\hline & & Copper & - & - & - \\
\hline & \multirow[t]{4}{*}{$\mathrm{HCl}+\mathrm{inh}$} & Aluminium & 15.30 & $\mathrm{Al}_{2} \mathrm{O}_{3}$ & 48.05 \\
\hline & & Silicon & 11.75 & $\mathrm{SiO}_{2}$ & 43.49 \\
\hline & & Copper & 0.33 & $\mathrm{CuO}$ & 1.61 \\
\hline & & Chlorur & 3.13 & $\mathrm{Cl}^{-}$ & 6.84 \\
\hline & \multirow[t]{3}{*}{$\mathrm{H}_{2} \mathrm{SO}_{4}+\mathrm{inh}$} & Aluminium & 47.01 & $\mathrm{Al}_{2} \mathrm{O}_{3}$ & 69.90 \\
\hline & & Silicon & 16.90 & $\mathrm{SiO}_{2}$ & 29.62 \\
\hline & & Copper & 0.21 & $\mathrm{CuO}$ & 0.48 \\
\hline \multirow[t]{10}{*}{ E150 } & \multirow[t]{3}{*}{ bare } & Aluminium & 59.15 & $\mathrm{Al}_{2} \mathrm{O}_{3}$ & 79.24 \\
\hline & & Silicon & 12.43 & $\mathrm{SiO}_{2}$ & 19.62 \\
\hline & & Copper & 0.55 & $\mathrm{CuO}$ & 1.14 \\
\hline & \multirow[t]{4}{*}{$\mathrm{HCl}+\mathrm{inh}$} & Aluminium & 18.87 & $\mathrm{Al}_{2} \mathrm{O}_{3}$ & 76.01 \\
\hline & & Silicon & 4.35 & $\mathrm{SiO}_{2}$ & 20.65 \\
\hline & & Copper & 0.41 & $\mathrm{CuO}$ & 2.55 \\
\hline & & Chlorur & 0.28 & $\mathrm{Cl}^{-}$ & 0.79 \\
\hline & \multirow{3}{*}{$\mathrm{H}_{2} \mathrm{SO}_{4}+\mathrm{inh}$} & Aluminium & 45.92 & $\mathrm{Al}_{2} \mathrm{O}_{3}$ & 70.71 \\
\hline & & Silicon & 14.71 & $\mathrm{SiO}_{2}$ & 26.71 \\
\hline & & Copper & 1.07 & $\mathrm{CuO}$ & 2.58 \\
\hline
\end{tabular}

corroded in $\mathrm{H}_{2} \mathrm{SO}_{4}$ medium comparing to the $\mathrm{HCl}$ medium. It is also seen that the corrosion decreases in both mediums by adding inhibitor and the surface has more homogeneous structure comparing to the medium without inhibitor. The EDX mapping microphotographs given in Figs. 2, 4 and 6 indicate that the electrode surface in $\mathrm{H}_{2} \mathrm{SO}_{4}$ is nearly similar to bare electrode surface. Aluminium which is stated as red separates from the surface a little shows that the corrosion level is low in $\mathrm{H}_{2} \mathrm{SO}_{4}$ medium. The electrode surface in $\mathrm{HCl}+20 \mathrm{mM} \mathrm{3m1p3ol} \mathrm{medium} \mathrm{changes} \mathrm{completely.}$ Aluminium separates from the surface and the chlorine ions which is stated as yellow show the presence of complexes. Silicon stated as green in $\mathrm{HCl}$ medium becomes prominent because the corrosion decreases the percentage of aluminium. As it is seen in the results of EDX analysis, the percentage of Si on the metal surface was increased. The EDX analysis of these alloys is given in Tables 2 and 3. It is seen that the surface structure of electrode consists metal oxides.

If SEM and EDX microphotographs, EDX analysis and AAS results are interpreted, it is seen that there are three phases in SEM microphotographs of bare surface of E110 alloy. White phases show Si, grey phase shows the compounds of intermetallics and homogeneous region represents the matrix region which is rich of $\mathrm{Al}$. The bare surface images of EDX mapping consist of aluminium oxides which are rich of Al. The images of EDX mapping show that there are $\mathrm{Al}, \mathrm{Cu}, \mathrm{Si}$ and $\mathrm{O}$ on the surface. $\mathrm{Al}, \mathrm{Cu}$ and $\mathrm{Si}$ are in the oxide form on the surface. 
Table 3. EDX analyses results of E160, E171, E195 alloys stored during 24 hours in acid and containing inhibitor acid solutions

\begin{tabular}{|c|c|c|c|c|c|}
\hline Sample & & Element & $\%$ atom & Type of oxide & wt $\%$ oxide \\
\hline \multirow[t]{10}{*}{ E160 } & \multirow[t]{3}{*}{ bare } & Aluminium & 56.61 & $\mathrm{Al}_{2} \mathrm{O}_{3}$ & 72.99 \\
\hline & & Silicon & 17.13 & $\mathrm{SiO}_{2}$ & 26.03 \\
\hline & & Copper & 0.48 & $\mathrm{CuO}$ & 0.98 \\
\hline & \multirow[t]{4}{*}{$\mathrm{HCl}+$ inh } & Aluminium & 11.59 & $\mathrm{Al}_{2} \mathrm{O}_{3}$ & 28.51 \\
\hline & & Silicon & 20.21 & $\mathrm{SiO}_{2}$ & 58.59 \\
\hline & & Copper & 1.49 & $\mathrm{CuO}$ & 5.72 \\
\hline & & Chlorur & 4.20 & $\mathrm{Cl}^{-}$ & 7.18 \\
\hline & \multirow[t]{3}{*}{$\mathrm{H}_{2} \mathrm{SO}_{4}+\mathrm{inh}$} & Aluminium & 45.59 & $\mathrm{Al}_{2} \mathrm{O}_{3}$ & 70.89 \\
\hline & & Silicon & 14.62 & $\mathrm{SiO}_{2}$ & 26.80 \\
\hline & & Copper & 0.95 & $\mathrm{CuO}$ & 2.32 \\
\hline \multirow[t]{10}{*}{ E171 } & \multirow[t]{3}{*}{ bare } & Aluminium & 59.03 & $\mathrm{Al}_{2} \mathrm{O}_{3}$ & 73.80 \\
\hline & & Silicon & 17.62 & $\mathrm{SiO}_{2}$ & 25.97 \\
\hline & & Copper & 0.12 & $\mathrm{CuO}$ & 0.23 \\
\hline & \multirow[t]{4}{*}{$\mathrm{HCl}+\mathrm{inh}$} & Aluminium & 10.82 & $\mathrm{Al}_{2} \mathrm{O}_{3}$ & 57.66 \\
\hline & & Silicon & 4.52 & $\mathrm{SiO}_{2}$ & 28.39 \\
\hline & & Copper & - & - & - \\
\hline & & Chlorur & 3.76 & $\mathrm{Cl}^{-}$ & 13.95 \\
\hline & \multirow[t]{3}{*}{$\mathrm{H}_{2} \mathrm{SO}_{4}+\mathrm{inh}$} & Aluminium & 58.00 & $\mathrm{Al}_{2} \mathrm{O}_{3}$ & 75.31 \\
\hline & & Silicon & 16.13 & $\mathrm{SiO}_{2}$ & 24.69 \\
\hline & & Copper & - & - & - \\
\hline \multirow[t]{11}{*}{ E195 } & \multirow[t]{4}{*}{ bare } & Aluminium & 37.46 & $\mathrm{Al}_{2} \mathrm{O}_{3}$ & 48.52 \\
\hline & & Silicon & 32.70 & $\mathrm{SiO}_{2}$ & 49.91 \\
\hline & & Copper & 0.38 & $\mathrm{CuO}$ & 0.77 \\
\hline & & Magnezium & 1.29 & $\mathrm{MgO}$ & 0.80 \\
\hline & \multirow[t]{3}{*}{$\mathrm{HCl}+$ inh } & Aluminium & 28.91 & $\mathrm{Al}_{2} \mathrm{O}_{3}$ & 40.65 \\
\hline & & Silicon & 26.96 & $\mathrm{SiO}_{2}$ & 49.84 \\
\hline & & Copper & 7.73 & $\mathrm{Cl}^{-}$ & 8.43 \\
\hline & \multirow[t]{4}{*}{$\mathrm{H}_{2} \mathrm{SO}_{4}+\mathrm{inh}$} & Aluminium & 39.57 & $\mathrm{Al}_{2} \mathrm{O}_{3}$ & 58.23 \\
\hline & & Silicon & 27.40 & $\mathrm{SiO}_{2}$ & 39.71 \\
\hline & & Copper & 0.57 & $\mathrm{CuO}$ & 1.31 \\
\hline & & Magnezium & 1.06 & $\mathrm{MgO}$ & 0.75 \\
\hline
\end{tabular}

E110 alloy is the second alloy whose $\mathrm{Cu}$ content is the highest level while its Si content is the lowest level. $\mathrm{Al}-\mathrm{Si}$ double system is a eutectic system. The eutectic point can be indicated as $12.2 \% \pm 0.1 \mathrm{Si}$ [36]. According to Al-Si double phase diagram Si containing of E110 alloy comes to the point six of 5.2\% Si eutectic below in phase diagram of $\mathrm{Al}-\mathrm{Si}$ double system.

When SEM images in $\mathrm{HCl}$ medium are examined, it can be seen that the metal surface is corroded significantly. $\mathrm{Al}$ and the other alloy elements pass through the solution the most in $\mathrm{HCl}$ medium comparing to the AAS results. When the inhibitor added in it, the other alloy elements decrease except Fe forms dissoluble complexes with $\mathrm{Cl}^{-}$. When the SEM images examined for $\mathrm{HCl}+20 \mathrm{mM} 3 \mathrm{~m} 1 \mathrm{p} 3 \mathrm{ol}$ medium, smoother structure which is not sharp can be seen instead of spinose structure in $\mathrm{HCl}$ medium. When EDX is examined, $\mathrm{Cl}^{-}$can be seen on the surface where $\mathrm{Cl}^{-}$forms lumps probably in the form $\mathrm{AlCl}_{4}^{-}$dissoluble complexes. Si remains unsolved. Because $\mathrm{Al}$ decreases on the surface, inhibition occurs less compared with $\mathrm{H}_{2} \mathrm{SO}_{4}$ medium and the results of EDX analysis confirm also with these findings. While $\mathrm{Al}, \mathrm{Si}$ decrease in $\mathrm{HCl}$ medium, $\mathrm{Cu}$ increases. The increase of $\mathrm{Cu}$ content may cause the increased effect of the inhibitor. The amount of element passing through the solution in $\mathrm{HCl}+20 \mathrm{mM} 3 \mathrm{~m} 1 \mathrm{p} 3 \mathrm{ol}$ medium decreases. When SEM microphotographs are examined, the surface is smoother, more homogeneous and no spinose structure can be seen in $\mathrm{H}_{2} \mathrm{SO}_{4}$ medium 
Table 4. The element analyses of alloys in the solution (ppm) waited 24 hours in different solutions

\begin{tabular}{|c|c|c|c|c|c|c|}
\hline Alloy & Medium & $\mathrm{Al}$ & $\mathrm{Cu}$ & $\mathrm{Fe}$ & $\mathrm{Mg}$ & $\mathrm{Zn}$ \\
\hline \multirow[t]{4}{*}{ E110 } & $\mathrm{HCl}$ & 294.31 & 0.25 & 1.14 & 1.14 & 1.86 \\
\hline & $\mathrm{HCl}+\mathrm{inh}$ & 94.61 & 0.06 & 1.43 & 0.79 & 1.71 \\
\hline & $\mathrm{H}_{2} \mathrm{SO}_{4}$ & 2.79 & 0.03 & 0.15 & 0.02 & 0.39 \\
\hline & $\mathrm{H}_{2} \mathrm{SO}_{4}+\mathrm{inh}$ & 1.69 & 0.02 & 0.18 & - & 0.24 \\
\hline \multirow[t]{4}{*}{ E140 } & $\mathrm{HCl}$ & 619.50 & 0.09 & 0.37 & 14.14 & 0.25 \\
\hline & $\mathrm{HCl}+\mathrm{inh}$ & 289.58 & 0.18 & 2.41 & 1.10 & 3.74 \\
\hline & $\mathrm{H}_{2} \mathrm{SO}_{4}$ & 2.67 & 0.02 & 0.23 & 0.02 & 0.20 \\
\hline & $\mathrm{H}_{2} \mathrm{SO}_{4}+\mathrm{inh}$ & 1.74 & 0.08 & 0.61 & 0.15 & 1.18 \\
\hline \multirow[t]{4}{*}{ E150 } & $\mathrm{HCl}$ & 374.60 & 1.06 & 2.00 & 1.44 & 5.10 \\
\hline & $\mathrm{HCl}+\mathrm{inh}$ & 73.51 & 0.04 & 0.63 & 0.19 & 1.02 \\
\hline & $\mathrm{H}_{2} \mathrm{SO}_{4}$ & 5.34 & 0.06 & 0.77 & 0.05 & 0.24 \\
\hline & $\mathrm{H}_{2} \mathrm{SO}_{4}+\mathrm{inh}$ & 1.91 & 0.02 & 0.54 & 1.93 & 8.91 \\
\hline \multirow[t]{4}{*}{ E160 } & $\mathrm{HCl}$ & 380.97 & 0.38 & 2.75 & 1.33 & 3.56 \\
\hline & $\mathrm{HCl}+\mathrm{inh}$ & 246.74 & 0.14 & 1.97 & 0.91 & 3.00 \\
\hline & $\mathrm{H}_{2} \mathrm{SO}_{4}$ & 2.40 & 0.02 & 0.21 & 0.02 & 0.14 \\
\hline & $\mathrm{H}_{2} \mathrm{SO}_{4}+\mathrm{inh}$ & 10.18 & 0.018 & 0.99 & 0.99 & 4.83 \\
\hline \multirow[t]{4}{*}{ E171 } & $\mathrm{HCl}$ & 742.71 & 2.48 & 4.91 & 7.82 & 2.94 \\
\hline & $\mathrm{HCl}+\mathrm{inh}$ & 242.79 & 0.015 & 1.14 & 1.92 & 1.86 \\
\hline & $\mathrm{H}_{2} \mathrm{SO}_{4}$ & 5.65 & 0.012 & 0.24 & 0.15 & 0.09 \\
\hline & $\mathrm{H}_{2} \mathrm{SO}_{4}+\mathrm{inh}$ & 2.69 & 0.33 & 0.68 & 0.096 & 15.65 \\
\hline \multirow[t]{4}{*}{ E195 } & $\mathrm{HCl}$ & 254.18 & 0.14 & 0.33 & 3.79 & 2.95 \\
\hline & $\mathrm{HCl}+\mathrm{inh}$ & 211.78 & 0.11 & 0.20 & 2.97 & 0.90 \\
\hline & $\mathrm{H}_{2} \mathrm{SO}_{4}$ & 4.89 & 0.01 & 0.22 & 0.61 & 0.19 \\
\hline & $\mathrm{H}_{2} \mathrm{SO}_{4}+\mathrm{inh}$ & 3.94 & 0.05 & 0.21 & 0.39 & 0.16 \\
\hline
\end{tabular}

Table 5. The corrosion rates in $1 \mathrm{~N} \mathrm{HCl}, 1 \mathrm{~N} \mathrm{H}_{2} \mathrm{SO}_{4}$ and containing $20 \mathrm{Mm} \mathrm{3m1p3ol} \mathrm{into} 1 \mathrm{~N} \mathrm{H}_{2} \mathrm{SO}_{4}$ and $1 \mathrm{~N} \mathrm{HCl}$ solutions

\begin{tabular}{|c|c|c|c|c|c|c|c|c|}
\hline \multirow[t]{3}{*}{ Metal/Alloy } & \multirow{2}{*}{\multicolumn{2}{|c|}{$\begin{array}{c}1 \mathrm{~N} \mathrm{H}_{2} \mathrm{SO}_{4} \\
i_{\text {cor }}, \mathrm{mA} / \mathrm{cm}^{2}\end{array}$}} & \multirow{2}{*}{\multicolumn{2}{|c|}{$\frac{1 \mathrm{~N} \mathrm{HCl}}{i_{\text {cor }}, \mathrm{mA} / \mathrm{cm}^{2}}$}} & \multirow{2}{*}{\multicolumn{2}{|c|}{$\begin{array}{c}1 \mathrm{~N} \mathrm{H}_{2} \mathrm{SO}_{4}+\mathrm{inh} \\
i_{\text {cor }}, \mathrm{mA} / \mathrm{cm}^{2}\end{array}$}} & \multirow{2}{*}{\multicolumn{2}{|c|}{$\begin{array}{c}1 \mathrm{~N} \mathrm{HCl}+\text { inh } \\
i_{\text {cor }}, \mathrm{mA} / \mathrm{cm}^{2}\end{array}$}} \\
\hline & & & & & & & & \\
\hline & T.E. & L.P. & T.E. & L.P. & 0.16 & 0.16 & 1.4 & 1.26 \\
\hline $\mathrm{Al}$ & 0.60 & 0.63 & 20.0 & 20.0 & 0.01 & - & 0.4 & - \\
\hline $\mathrm{Cu}$ & 1 & - & 4 & - & 15 & 10 & 178 & 180 \\
\hline $\mathrm{Zn}$ & 131 & 135 & 316 & 315 & 29 & 35 & 50 & 52 \\
\hline $\mathrm{Mg}$ & 100 & 100 & 155 & 158 & 1.01 & 1.00 & 15 & 4 \\
\hline E110 & 10.0 & 10.0 & 63 & 69 & 0.17 & 0.16 & 33 & 32 \\
\hline E140 & 2.5 & 2.5 & 100 & 100 & 1.26 & 0.80 & 32 & 32 \\
\hline E150 & 10.0 & 10.0 & 99 & 100 & 0.15 & 0.16 & 45 & 48 \\
\hline E160 & 4.0 & 4.0 & 138 & 138 & 0.20 & 0.18 & 30 & 30 \\
\hline E171 & 3.20 & 3.20 & 125 & 126 & 0.12 & 0.12 & 21 & 20 \\
\hline E195 & 5.60 & 5.60 & & & & & & \\
\hline
\end{tabular}

compared to that of $\mathrm{HCl}$ medium. Passing from the surface to the solution was prominently decreases in $\mathrm{H}_{2} \mathrm{SO}_{4}$ solution according to in $\mathrm{HCl}$ in AAS results. The inhibition occurs because Al remains on the surface. Also the inhibitive effect of sulphate ion accelerates this case. When SEM microphotographs of $\mathrm{H}_{2} \mathrm{SO}_{4}+$ 
$a$

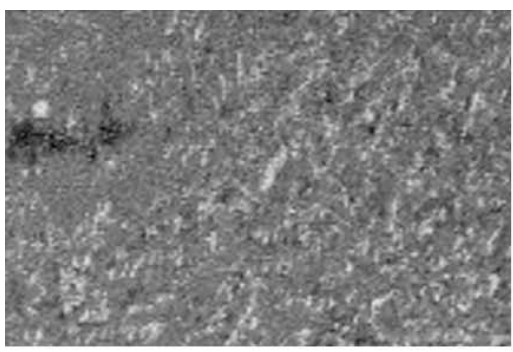

E140

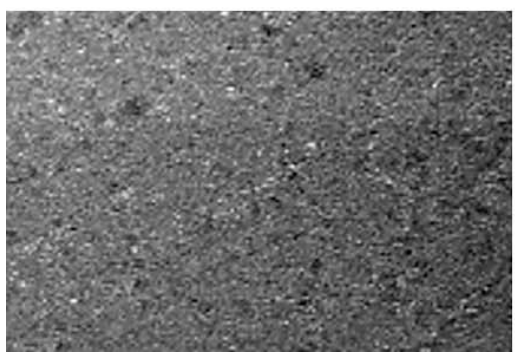

$b$
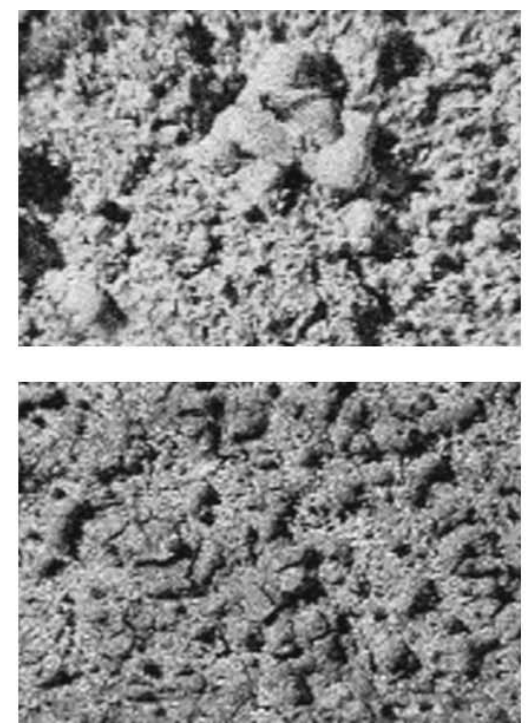

$c$
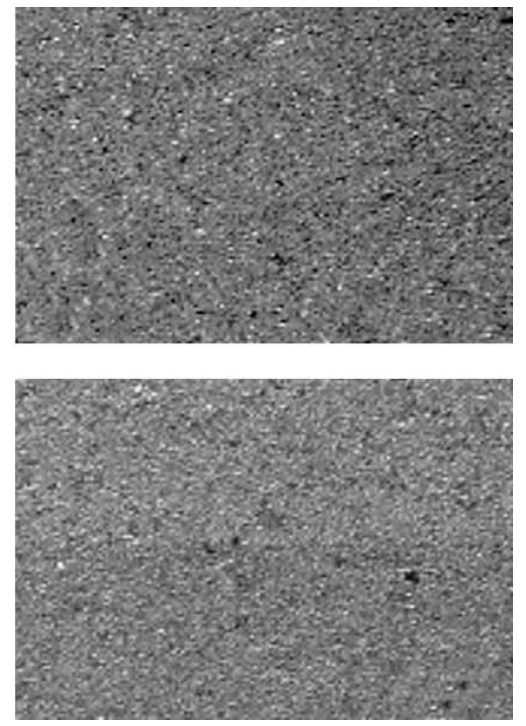

Fig. 2. EDX mapping microfotographs (a) bare, (b) $\mathrm{HCl}+20 \mathrm{mM}$ inhibitor, (c) $\mathrm{H}_{2} \mathrm{SO}_{4}+20 \mathrm{mM} 3 \mathrm{~m} 1 \mathrm{p} 3 \mathrm{ol}$.
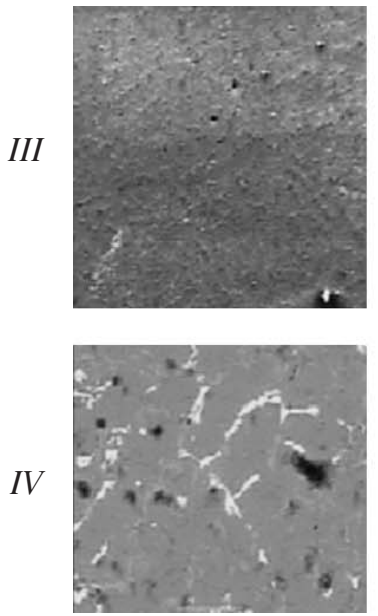

$b$
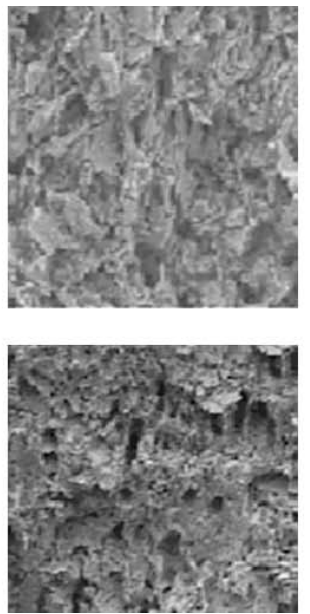

c
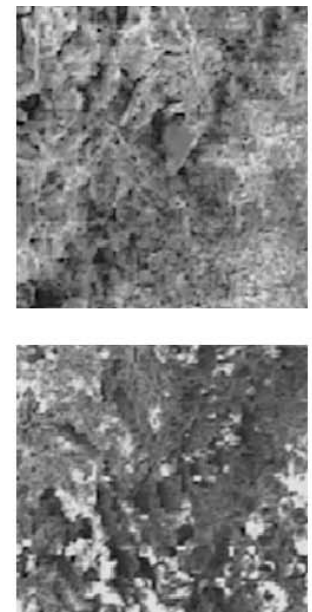

$d$
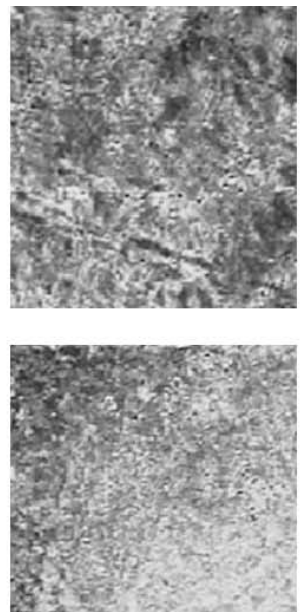

$e$
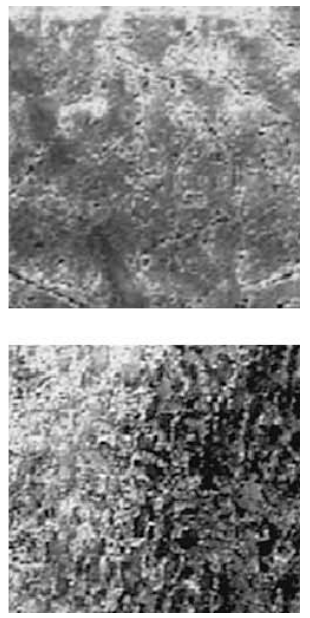

Fig. 3. SEM microphotographies of Al alloys III-E150, IV-E160, (a) bare surface, (b) $1 \mathrm{~N} \mathrm{HCl,} \mathrm{(c)} 1 \mathrm{~N} \mathrm{HCl}+20 \mathrm{mM} 3$-metil1-pentin-3-ol(3m1p3ol), (d) $1 \mathrm{~N} \mathrm{H}_{2} \mathrm{SO}_{4}$ and (e) $1 \mathrm{~N} \mathrm{H}_{2} \mathrm{SO}_{4}+20 \mathrm{mM}$ 3-metil-1-pentin-3-ol.

$20 \mathrm{mM}$ 3m1p3ol medium examined, again more homogeneous structure can be seen. When EDX mapping results are examined, the surface gets rich of $\mathrm{Al}$ and it can be seen that it consists of much more Al than bare surface structure does. Al content increases on the surface while Si content decreases. Inhibition occurs much more and the passing elements through the solution decrease in AAS results. There is a matrix region which is rich of $\mathrm{Al}$ on bare surface in EDX microphotographs and the surface is composed of $\mathrm{Al}_{2} \mathrm{O}_{3}, \mathrm{SiO}_{2}$ and $\mathrm{CuO}$ SEM, EDX, AAS results of E140 alloy. Three phases like E110 alloy can also be seen from the SEM microphotographs of the bare surface. When the compound of E140 alloy is examined, it is seen that there is 12\%
$\mathrm{Si}$ eutectic structure and its $\mathrm{Cu}$ content is a little. When SEM microphotographs of $\mathrm{HCl}$ are examined, there are spinose $\mathrm{Si}$ crystals on the surface which is corroded extremely. According to AAS results, the amounts of Al and $\mathrm{Mg}$ passing through the solution for $\mathrm{HCl}$ medium is much more compared to that of E110 alloy. The images of $\mathrm{HCl}+20 \mathrm{mM} \mathrm{3m1p3ol} \mathrm{medium} \mathrm{are} \mathrm{more}$ homogenous and $\mathrm{Si}$ increases in the EDX mapping images because $\mathrm{Al}$ decreases on the surface. The brown structures indicate that $\mathrm{Al}_{2} \mathrm{O}_{3}, \mathrm{SiO}_{2}$ and $\mathrm{Al}_{2} \mathrm{O}_{3}$ decrease on the surface of $\mathrm{HCl}+20 \mathrm{mM} 3 \mathrm{~m} 1 \mathrm{p} 3 \mathrm{ol}$ medium and $\mathrm{Cu}$ increases. The increasing $\mathrm{Cu}$ on the metal surface leads to the increasing of inhibition effect. While the amount of $\mathrm{Cu}, \mathrm{Fe}, \mathrm{Mg}$, $\mathrm{Zn}$ passing through the solution 
$a$

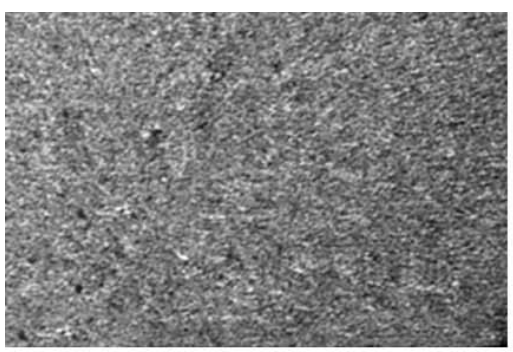

E150

E160

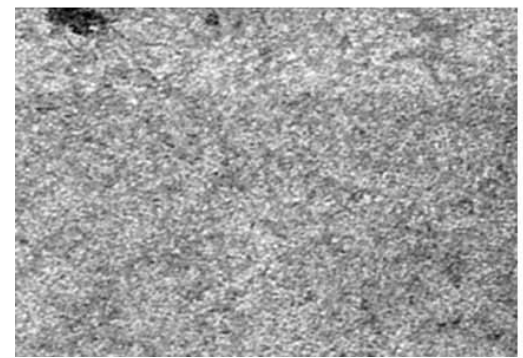

$b$
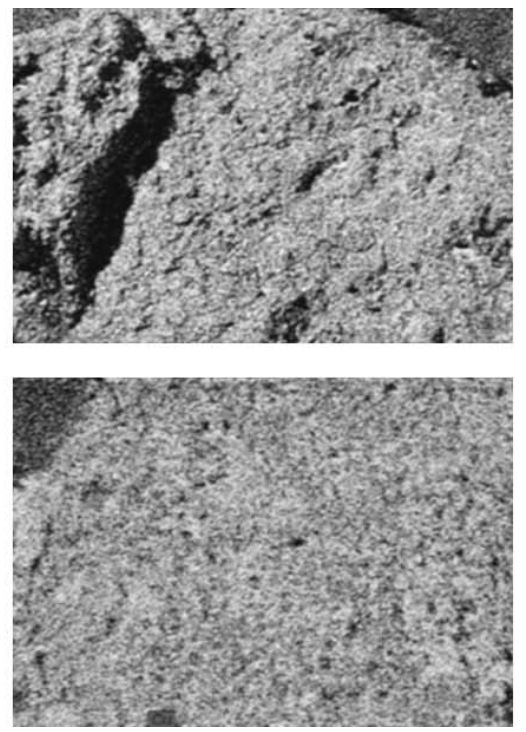

$c$
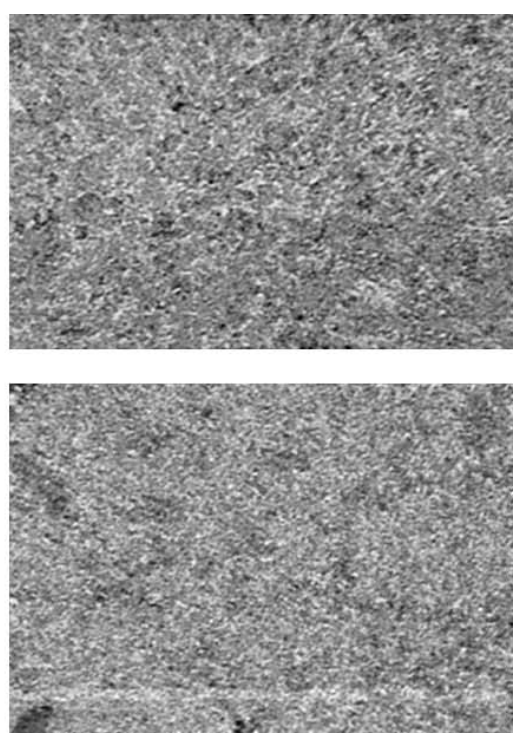

Fig. 4. EDX map microfotographs (a) bare, (b) $\mathrm{HCl}+20 \mathrm{mM}$ inhibitor, (c) $\mathrm{H}_{2} \mathrm{SO}_{4}+20 \mathrm{mM} 3 \mathrm{mlp} 3 \mathrm{ol}$.
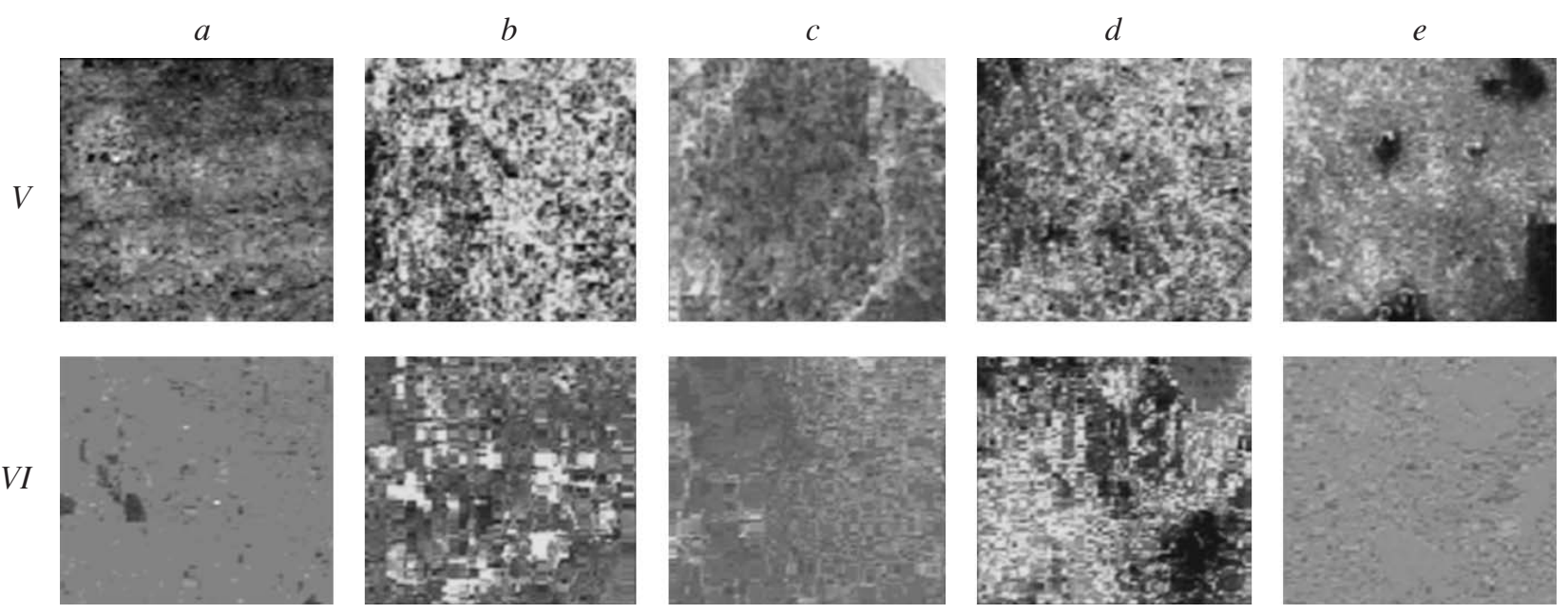

Fig. 5. SEM microscopic images of Al alloys $V-E 171, V I-E 195,(a)$ bare surface, (b) $1 \mathrm{~N} \mathrm{HCl,} \mathrm{(c)} 1 \mathrm{~N} \mathrm{HCl}+20 \mathrm{mM} 3-\mathrm{metil}-1-$ pentin-3-ol(3m1p3ol), (d) $1 \mathrm{~N} \mathrm{H}_{2} \mathrm{SO}_{4}$ and (e) $1 \mathrm{~N} \mathrm{H}_{2} \mathrm{SO}_{4}+20 \mathrm{mM}$ 3-metil-1-pentin-3-ol.

increase, $\mathrm{Al}$ decreases on the surfaces. Increasing $\mathrm{Al}$ on the metal surface occurs inhibition. According to EDX mapping analysis $\mathrm{Cu}, \mathrm{Si}$ and $\mathrm{Cl}^{-}$increased on the surface. When AAS result is examined, the amount of element passing through the surface decreases very much, that causes the increase of inhibition comparing to the $\mathrm{HCl}$ medium.

If SEM and EDX microphotographs, EDX analysis and AAS results are interpreted for E150 alloy, it is seen that there are eutectic structures on bare surface of E150 alloy. The images of EDX mapping show $\mathrm{Al}, \mathrm{Cu}$, $\mathrm{Si}$ and $\mathrm{O}$ the presence of elements on the surface. $\mathrm{Al}, \mathrm{Cu}$ and $\mathrm{Si}$ are in the oxide form on the surface. When SEM images in $\mathrm{HCl}$ medium are examined, it can be seen that the surface is corroded significantly and seen that irregular crystal structure. $\mathrm{Al}$ and the other alloying elements pass through the solution the most in $\mathrm{HCl}$ medium comparing to the others alloys. When the inhibitor added in it, $\mathrm{Al}$ completely pass the solution. When the SEM images are examined for $\mathrm{HCl}+20 \mathrm{mM}$ $3 \mathrm{~m} 1 \mathrm{p} 3 \mathrm{ol}$ medium, smoother structure which is not sharp can be seen instead of spinose structure in $\mathrm{HCl}$ medium. Because $\mathrm{Al}$ decreases on the surface, less inhibition occurs comparing to that of $\mathrm{H}_{2} \mathrm{SO}_{4}$ medium and the results of EDX analysis confirm these findings. The amount of element passing through the solution in $\mathrm{HCl}+20 \mathrm{mM} 3 \mathrm{~m} 1 \mathrm{p} 3 \mathrm{ol}$ medium decreases. When SEM microphotographs are examined, the surface is 
$a$
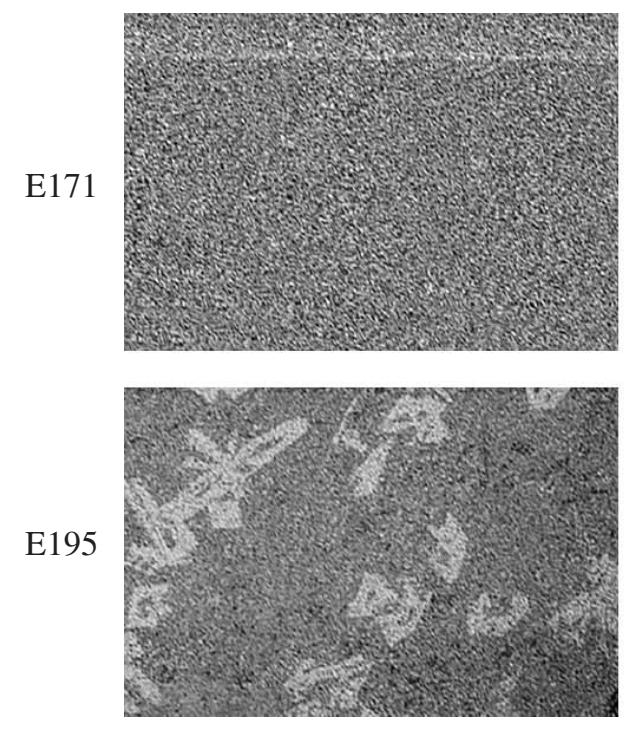

$b$
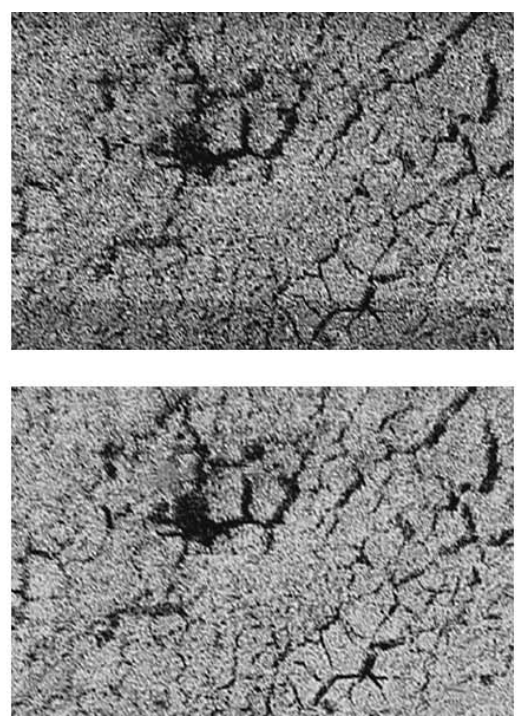

$c$
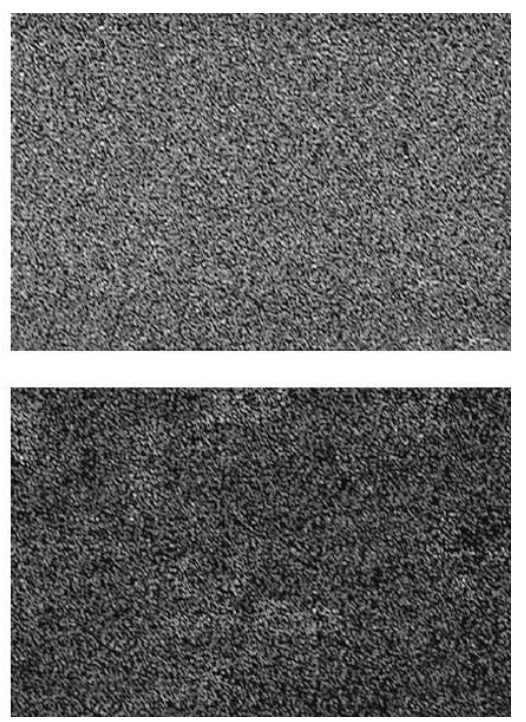

Fig. 6. EDX map microphotographies (a) bare, (b) $\mathrm{HCl}+20 \mathrm{mM}$ inhibitor, (c) $\mathrm{H}_{2} \mathrm{SO}_{4}+20 \mathrm{mM} 3 \mathrm{~m} 1 \mathrm{p} 3 \mathrm{ol}$.

smoother, more homogeneous and no spinose structure can be seen in $\mathrm{H}_{2} \mathrm{SO}_{4}$ medium comparing to the $\mathrm{HCl}$ medium. Passing from the surface to the solution prominently decreases in AAS results. The inhibition occurs because $\mathrm{Al}$ remains on the surface. Also the inhibitive effect of sulphate ion accelerates this case. When SEM microphotographs of $\mathrm{H}_{2} \mathrm{SO}_{4}+20 \mathrm{mM} 3 \mathrm{~m} 1 \mathrm{p} 3 \mathrm{ol}$ medium are examined, again more homogeneous structure can be seen. When EDX mapping results are examined, the surface gets rich with $\mathrm{Al}$ and it can be seen that it consists of much more $\mathrm{Al}$ than bare surface structure does. Because $\mathrm{Al}$ increases on the surface while less $\mathrm{Si}$ element is detected, inhibition occurs much more and the elements passing through the solution decrease significantly in AAS results.

When the results of SEM, EDX mapping and AAS and EDX analysis of E171 alloy are examined, it is the alloy whose $\mathrm{Mg}$, Mn content is the most, but the amount of $\mathrm{Cu}$ is the least. Al-Si is an alloy that is very similar to the structure of eutectic in phases diagram. Homogenous smooth distributed layers can be seen in the SEM image of bare surface and the structure of $\mathrm{HCl}$ images is very similar to the other alloys. And we can conclude from AAS results that the amount of Al passing through solution is the most. The other alloying elements act in the same way, too. The surface is composed of $\mathrm{Al}_{2} \mathrm{O}_{3}, \mathrm{SiO}_{2}$ and $\mathrm{CuO}$ according to the SEM microphotographs of bare surface. The amount of that passing through the solution in $\mathrm{HCl}+20 \mathrm{mM} \mathrm{3m1p3ol}$ medium is less comparing to the of $\mathrm{HCl}$ medium. When SEM images are examined in $\mathrm{HCl}$ medium, $\mathrm{Si}$ dendrites (the structures like tree) can be seen on the surface and it is known that the surface is more homogeny in $\mathrm{H}_{2} \mathrm{SO}_{4}+20 \mathrm{mM} 3 \mathrm{~m} 1 \mathrm{p} 3 \mathrm{ol}$ medium and it is similar to the structure of bare surface. The excess of $\mathrm{SiO}_{2}$ on the surface can be seen in EDX mapping images. While $\mathrm{Al}_{2} \mathrm{O}_{3}$ on the surface decreases, $\mathrm{SiO}_{2}$ is almost the same on bare surface in EDX analysis. $\mathrm{Zn}$ passes the solution the most in $\mathrm{H}_{2} \mathrm{SO}_{4}+20 \mathrm{mM} 3 \mathrm{~m} 1 \mathrm{p} 3 \mathrm{ol}$ medium when AAS results are examined. $\mathrm{Zn}$ decreases on the surface, which may cause the effect that increases the inhibition.

When SEM, EDX mapping and AAS and EDX analysis results are examined for E195 alloy, SEM images of bare surface state that the surface has a homogenous structure, the matrix region which is rich with Al, grey regions show intermetallic compounds, black regions show the defects during the casting. It can be seen that the surface are corroded in $\mathrm{HCl}$ medium and it has a spinose structure and there are two light and dark phases. E195 alloy is the alloy that has the highest level of Si. Al-Si shows an over eutectic structure in double phases diagrams and Si's perform segregations by becoming together in alloy because Si level is high. It can be seen clearly in EDX mapping images, too. There are $\mathrm{Al}_{2} \mathrm{O}_{3}, \mathrm{SiO}_{2}$ and $\mathrm{CuO}$ on the surface where MgO's occur because E195 alloy has the highest level of $\mathrm{Mg}$. When EDX analysis results of $\mathrm{HCl}$ medium are examined, the percentages of $\mathrm{Al}_{2} \mathrm{O}_{3}$ and $\mathrm{SiO}_{2}$ are almost the same on the bare surface and there is $\mathrm{MgO}$ on it. Silicon segregations, $\mathrm{Al}_{2} \mathrm{O}_{3}, \mathrm{SiO}_{2}, \mathrm{MgO}$ can be seen in EDX mapping images of bare surface. It can be seen that the amount of $\mathrm{Al}$ in this alloy passes through the solution is less compared to that of the others in AAS results of $\mathrm{HCl}$ medium of E195 alloy. The white phases in $\mathrm{HCl}$ medium seem gone and they look like one normal phase in SEM images of $\mathrm{HCl}+20 \mathrm{mM}$ 3m1p3ol medium. Si bars seem less sharp. And it can be seen in EDX map that Al remains little on the surface, light brown structures are aluminium chlorur complexes and there are $\mathrm{Si}$ segregations and $\mathrm{CuO}$. The 
amount of element passed through the solution decreases too according to the analysis results. The percentage of $\mathrm{SiO}$ on the surface does not change in EDX analysis results compared to that of $\mathrm{HCl}$ medium while $\mathrm{Al}$ decreases. There are also $\mathrm{Cl}^{-}$ions on the surface. As a result of this the inhibition level is low in $\mathrm{HCl}$ medium. White Si bars seem in SEM microphotographs of $\mathrm{H}_{2} \mathrm{SO}_{4}$ medium and the segregations can be seen again in the shape of layer. The segregations show a spreading in the shape of layer in $\mathrm{H}_{2} \mathrm{SO}_{4}+20 \mathrm{mM}$ $3 \mathrm{~m} 1 \mathrm{p} 3 \mathrm{ol}$ and the surface is indentationed. In EDX mapping images of $\mathrm{H}_{2} \mathrm{SO}_{4}+20 \mathrm{mM} 3 \mathrm{~m} 1 \mathrm{p} 3 \mathrm{ol}$, the percentage of $\mathrm{Al}_{2} \mathrm{O}_{3}$ is more than on the bare surface. While $\mathrm{CuO}$ increases on the surface, $\mathrm{Si}$ decreases. As $\mathrm{Al}$ and $\mathrm{Cu}$ levels increase on the surface, the inhibition increases too. When AAS results are examined, $\mathrm{Al}$ passes through the solution the least in $\mathrm{H}_{2} \mathrm{SO}_{4}+20 \mathrm{mM}$ 3 m1p3ol medium, which confirms the results above. The structure of electrode is made from the metal oxides according to the EDX analyses of these alloys are given in Tables 2 and 3.

In order to determine which alloying elements were corroded most, after Al alloys store during $24 \mathrm{hr}$ in $1 \mathrm{~N}$ $\mathrm{HCl}, 1 \mathrm{~N} \mathrm{HCl}+3 \mathrm{~m} 1 \mathrm{p} 3 \mathrm{ol}, 1 \mathrm{~N} \mathrm{H}_{2} \mathrm{SO}_{4}$ and $1 \mathrm{~N} \mathrm{H}_{2} \mathrm{SO}_{4}+$ $3 \mathrm{~m} 1 \mathrm{p} 3 \mathrm{ol}$ media the analyses of the solution was performed by VISTA AX, the spectrometer of atomic absorption. The obtained results are indicated in Table 4.

As it is seen in Table 5 the corrosion rate of metal alloys in $\mathrm{H}_{2} \mathrm{SO}_{4}$ medium is lower comparing to the $\mathrm{HCl}$ medium. This results shows a structure composed of both barrier and porous layer on aluminium alloys in $\mathrm{H}_{2} \mathrm{SO}_{4}$ medium. 3-methyl-1-pentyn-3-ol alcohol were taken in this study because it shows the best inhibitor efficiency in all alloys [21, 22]. Table 5 indicates that alcohol shows better inhibitor efficiency in $\mathrm{H}_{2} \mathrm{SO}_{4}$ medium comparing to the $\mathrm{HCl}$ medium. 3-methyl-1pentyn-3-ol was shown for all alloying elements inhibitor both in $\mathrm{H}_{2} \mathrm{SO}_{4}$ and $\mathrm{HCl}$ media, but it shows more inhibition on pure $\mathrm{Al}$ and $\mathrm{Cu}$. This case gives an idea that increase of alloying elements $\mathrm{Al}$ and $\mathrm{Cu}$ causes the increase of inhibitor efficiency. As a matter of fact, the analyses of solution and surface confirm our ideas. Al and $\mathrm{Cu}$ increase the inhibition effect of $3 \mathrm{~m} 1 \mathrm{p} 3 \mathrm{ol}$ more than $\mathrm{Mg}$ and $\mathrm{Zn}$ in $\mathrm{HCl}$ and $\mathrm{H}_{2} \mathrm{SO}_{4}$ (Table 4). As it is expected, very much active alloy elements pass through the phase of the solution of $\mathrm{Mg}, \mathrm{Zn}$ and $\mathrm{Al}$. For this reason the increase of copper occurs on surface. However, this increase is much more in $\mathrm{HCl}$ medium comparing to the $\mathrm{H}_{2} \mathrm{SO}_{4}$ medium. For this reason it can be said that 3-methyl-1-pentyn-3-ol show much more inhibition efficiency in $\mathrm{H}_{2} \mathrm{SO}_{4}$ medium comparing to the $\mathrm{HCl}$ medium. In our previous study [21, 22], the presence of various zones was shown on the surface of alloy. The results obtained from the analyses of SEM, EDX indicate that the main alloy elements on surface are in the compound of oxide. When the development of oxide film and the effect of $\mathrm{Cl}^{-}$and $\mathrm{SO}_{4}^{2-}$ ions on aluminium are examined, it is observed that $\mathrm{SO}_{4}^{2-}$ ions contribute to the growth of film. Whereas the thickness of oxide film increases on aluminium surface in $\mathrm{H}_{2} \mathrm{SO}_{4}$ medium, the film does not become thick because of the effect of $\mathrm{Cl}^{-}$ions-forming complex ions, dissolves the film layers in $\mathrm{HCl}$ medium. $\mathrm{Cl}^{-}$ions cause the corrosion of pitting by dissolving the film. In Polat's study (1997), it is stated that the ion of sulphate acts as a inhibitor for aluminium and it makes the surface passive in high concentration by forming $\mathrm{Al}(\mathrm{OH}) \mathrm{SO}_{4}$ [35]. The structure of oxide is double layered in $\mathrm{H}_{2} \mathrm{SO}_{4}$ medium and the bottom layer is in an intensive barrier layer and the top is in a porous layer formation. When the alcohol is adsorptioned on such surface, it probably covers the pore on the top layer and decreases the corrosion. This covering effect depends on the structure of alcohol and if the alcohol is small, this covering is well because it can access into these pore easily. However, it can be said that there is a partly change in this case because of the aluminium alloys in question and its different surface structure from pure aluminium. For example, if copper is a lot and alcohol is adsorbed on copper surface, the effect of inhibitor on the corrosion shows an increase depending on the adsorption and effecting between alcohol and copper surface or if the most of surface is composed of aluminium, the inhibitor efficiency is much more in this case because small alcohol molecules can access into pittings and can cover them easily (1-buten-3-ol is more active on alloy whose matrix part is very much and whose content is rich with aluminium in SEM photograph such as E 110, E 195 and E 171).

\section{CONCLUSIONS}

The corrosion of aluminium-silicon-copper alloys significantly decreases in $\mathrm{H}_{2} \mathrm{SO}_{4}$ and $\mathrm{HCl}$ mediums containing 3-methyl-1-pentyn-3-ol. This decrease is much more in $\mathrm{H}_{2} \mathrm{SO}_{4}$ medium. The active alloy elements, $\mathrm{Mg}, \mathrm{Zn}$ and $\mathrm{Al}$, dissolve much more in $\mathrm{H}_{2} \mathrm{SO}_{4}$ and $\mathrm{HCl}$ mediums. This dissolving is much more in $\mathrm{HCl}$ medium and the inhibitor efficiency is less because the percentages of $\mathrm{Cu}$ and $\mathrm{Al}$ is less on the rest of surface compared to that of $\mathrm{H}_{2} \mathrm{SO}_{4}$ medium and the corrosion products on the surface of alloys are the oxides essentially $\left(\mathrm{Al}_{2} \mathrm{O}_{3}, \mathrm{CuO}\right.$ and $\left.\mathrm{SiO}_{2}\right)$.

\section{ACKNOWLEDGMENTS}

The authors acknowledge the financial support of Afyon Kocatepe University (project no. 041.FENED.05) and Ankara University (project no. 2004-07-05-088).

\section{REFERENCES}

1. Andreatta, F., Terryn, H., and de Wit, J.H.W., Electrochim. Acta, 2004, vol. 49, p.2851.

2. Shimizu, K., Fujitani, H., Habazaki, H., et al., Corros. Sci., 2004, vol. 46, p. 2549. 
3. Shao, M., Fu, Y., Hu, R., and ve Lin, C., Materials Sci. Eng., Ser. A, 2003, vol. 344, p. 323.

4. Mazhar, A.A., Arab, S.T., and ve Noor, E.A., J. App. Electrochem., 2001, vol. 31, p. 1131.

5. Kral, M.V., McIntyre, H.R., and Smillie, M.J., Scripta Materialia, 2004, vol. 51, p. 215.

6. Chen, C.M., Yang, C.C., and Chaoa, C.G., Materials Sci. Eng., Ser. A, 2004, vol. 366, p. 183.

7. Joyce, M.R., Styles, C.M., and Reed, P.A.S., Int. J. Fatigue, 2003, vol. 25, p. 863.

8. Verdu, C., Cercueil, H., Communal, S., et al., Materials Sci. Forum, 1996, vols. 217-222, p. 1449.

9. Shiozawa, K., Tohda, Y., and Sun S.-M., Fatigue and Fracture Eng. Materials and Structures, 1997, vol. 20, p. 237.

10. Skallerud, B., Iveland, T., and Harkegard, G., Eng. Fracture Mechanics, 1993, vol. 44, p. 857.

11. Hoskin, G.A., Provan, J.W., and Gruzleski, J.E., Theoretical and Applied. Fracture Mechanics, 1988, vol. 10, p. 27.

12. Madelaine-Dupuich, O. and Stolarz, J., Materials Sci. Forum., 1996, vols. 217-222, p. 1343.

13. Plumtree, A. and Schafer, S., The Behaviour of Short Fatigue Cracks, London: Mechanical Engineering Publications, 1986, p. 215.

14. Inguanti, P.C., Proceedings of the 17th National SAMPE Technical Conference, 1985, p. 61.

15. Liao, H., Sun, Yu., and Sun, G., Materials Sci. Eng., Ser. A, 2002, vol. 335, p. 62.

16. Pillai, R.M., Biju Kumar1, K.S., and Pai, B.C., J. Materials Proc. Technol., 2004, vol. 146, p. 338.

17. Paez, M.A., Foong, T.M., Ni, C.T., et al., Corros. Sci., 1996, vol. 38 , no. 1, p. 59.
18. Zhou, X., Shimizu, K., Thompson, G.E., et al., Corros. Sci., 1999, vol. 41, no. 8, p. 1599.

19. Patermarakis, G. and ve Moussoutzanis, K., Corros. Sci., 2002, vol. 44, p. 1737.

20. Kowal, K., Deluccia, J., Josefowicz, J.Y., et al., J. Electrochem. Soc., 1996, vol. 143, no. 8, p. 2471.

21. Büyüksağ is A. and ve Aksüt, A.A., VIII International Corrosion Symposium, 2002, vol. A, p. 203.

22. Büyüksağ is A. and ve Aksüt, A.A., VIII International Corrosion Symposium, 2002, vol. B, p. 311.

23. Laz, M.M., Souto, R.M., Gonzalez, R., et al., Electrochim. Acta, 1992, vol. 37, no. 4, p. 655.

24. Polat, R., Ph.D. Thesis, Ankara, 1997, p. 306.

25. Emregül, K.C., Ph.D. Thesis, Ankara, 1997, p. 264.

26. Crossland, A.C., Thompson, G.E., Smith C.J.E., et al., Corros. Sci., 1999, vol. 41, no. 10, p. 2053.

27. Zhang, Q. and Wang, W., Materials Sci. Eng., Ser. A, 2002, vol. 280, p. 168.

28. Zhou, X., Shimizu, K., Thompson, G.E., et al., Corros. Sci., 1999, vol. 41, no. 6, p. 1089.

29. Thin Solid Films, 1985, vol. 123, p. 127.

30. Domingues, L., Fernandes, J.C.S., Cunha, Belo M.Da, et al., Corros. Sci., 2003, vol. 45, p. 149.

31. Tedeshi, R.J., Corrosion, 1975, vol. 31, no. 4, p. 130.

32. Fiaud, C., Harch, A., Mallouh, D., and ve Tzinmann, M., Corros. Sci., 1993, vol. 35, p. 1437.

33. Önal, A.N., Ph.D. Thesis, Ankara, 2000, p. 97.

34. Frigrani, A. and ve Trabanelli, R., Corrosion, 1999, vol. 55, no. 7 , p. 653.

35. Foley, R.T. and ve Nguyen, T.H., J. Electrochem. Soc., 1982, vol. 129, no. 3, p. 464.

36. ASM Handbook Commitie, ASM Metals Hanbook, American Society for Metals Park, 1975, Ohio, 7, 8, 10, Printed USA. 